\title{
USE OF LEARNING RESOURCES IN LEARNING HISTORY AT SMA NEGERI 5 TERNATE CITY
}

\author{
Gazali Far-Far ${ }^{1}$, Johan Pattiasina ${ }^{2}$ \\ ${ }^{1-2}$ History Education, Teaching and Education Faculty, Pattimura University, Ambon \\ farfargazali@gmail.com ${ }^{1}$, pattiasina_john@yahoo.com ${ }^{2}$
}

\begin{abstract}
In the learning process at school, learning resources are supporting indicators for achieving learning objectives. Apart from other supporting factors such as learning media, teachers and students. The purpose of this study is to determine the use of learning resources in history learning, and challenges and solutions in overcoming problems related to the use of learning resources in SMA Negeri Kota Ternate. In this study, using a qualitative method with descriptive research type, the research subjects were teachers who are teaching history, students and school heads. With the aim in order to explore the factors that have a correlation with the use of learning resources in learning history. To obtain data to support this research, the data collection process was carried out by means of observation, interviews and documentation.

Then to find out the validity of the data, it is carried out through qualitative analysis with an inductive logic approach, in which the syllogism is built based on specific things or data in the field and leads to general conclusions. Thus, this approach uses the logic of thinking to resemble a sitting pyramid. The results of the research obtained illustrate that, first, the use of learning resources in learning history at SMA Negeri 5 Ternate City is very good, messages, environment, tools, techniques and materials, although the use of textbooks is still a learning resource. Secondly, the obstacles that were found were the lack of learning resources such as textbooks, especially for class XI, and the availability of time.
\end{abstract}

Keyword: Resources for Learning, Learning, History

\begin{abstract}
Abstrak : Dalam proses pembelajaran di sekolah, sumber belajar merupakan indikator pendukung untuk mencapai tujuan pembelajaran. Selain dari faktor pendukung lainnya seperti media pembelajaran, guru dan siswa. Tujuan pada penelitian ini agar mengetahui penggunaan sumber belajar dalam pembelajaran sejarah, dan tantangan-maupun solusi dalam mengatasi permasalahan yang berkaitan dengan penggunaan sumber belajar di SMA Negeri Kota Ternate. Pada penelitian ini menggunakan metode kualitatif dengan jenis penelitian deskriptif maka subyek penelitian adalah guru mata pelajaran sejarah, siswa dan kepalah sekolah. Dengan tujuan agar untuk menggali faktor-faktor yang memiliki korelasi dengan penggunaan sumber belajar dalam pembelajaran sejarah. Untuk memperoleh data guna mendukung penelitian ini, maka proses pengumpulan data dilakukan dengan cara observasi, wawancara dan dokumentasi.

Kemudian untuk mengetahui keabsahan data, maka dilakukan melalui analisis-analisis kualitatif dengan pendekatan logika induktif, di mana silogisme dibangun berdasarkan pada hal-hal khusus atau data di lapangan dan bermuara pada kesimpulan-kesimpulan umum. Dengan demikian, pendekatan ini menggunakan logika berpikir menyerupai piramida duduk. Dari hasil penelitian yang diperoleh menggambarkan bahwa, pertama, penggunaan sumber belajar dalam pembelajaran sejarah di SMA Negeri 5 Kota Ternate sudah sangat baik, penggunaan dengan cara penggunaan pada manusia, pesan, lingkungan, alat, teknik dan bahan. Walaupun penggunaan buku teks masih sebagai sumber belajar. Kedua, kendala yang ditemukan yakni, minimnya sumber belajar seperti buku teks khususnya bagi kelas XI, serta ketersediaan waktu. Ketiga, solusi untuk menjawab kendala yang ada dengan cara guru dan siswa dapat memanfaatkan ketersediaan internet untuk bisa mengakses buku-buku berkaitan dengan materi yang diajarkan.
\end{abstract}

Kata Kunci : Sumber Belajar, Pembelajaran, Sejarah

\section{INTRODUCTION}

Teaching is an institutionalized process. It is not just a mere teaching-learning process. The education sector has become "the source center for all knowledge and schools are the only model or tool for transferring knowledge (Far-Far Gazali, 2020). In the world of education, learning can 
be assumed as a process to show a positive change that is displayed through new skills, skills and knowledge acquired through a combination of experience and learning. The results of the learning process are known as learning achievements. Therefore, learning is an important process, because these activities greatly determine the success process of the goals to be achieved. Learning literally means the learning process. Learning can be interpreted as a process of adding knowledge and insights through a series of activities carried out consciously by a person and resulting in changes in him/her, resulting in positive changes, and at the end new skills, skills and knowledge will be obtained (Saefuddin H. Asis \& Berdiati Ika, 2016). The explanation above is in line with what is expressed by Wina Sanjaya(Yana Wardhana, 2010)that learning objectives are abilities (competencies) or skills that are expected to be possessed by students after they carry out a certain learning process.

The changes displayed by students are the result of the learning process which can be observed through various forms, for example, attitudes, skills, habits, knowledge and appreciation / acceptance or appreciation. These changes can include his condition, knowledge or actions. Learning that has reached this stage is said to be successful and optimal. Furthermore, there is a learning process that is said to be incomplete and not optimal because the teacher cannot encourage students according to the personal aspects of the child. Thus according to (Musfiqon HM, 2012) that learning is a planned activity to gain knowledge and insight, so that a person's behavior changes towards maturity. The understanding that has been obtained is a source of value that influences a person to think, act and behave.

Making learning easier for students is the teacher's main task. For this reason, teachers are not only required to make the learning atmosphere comfortable and attractive, but also must be able to create learning methods that are appropriate to the circumstances of each student. Here, the teacher is required to really know the characteristics of each student. Thus, the methods and approaches applied are really in accordance with the self-development of the students who are the subject and the object of education itself (Baharuddin. H, 2015).

Thus, for a good and effective learning process with optimal learning outcomes, teachers are required to design learning systematically and measurably. The learning process can run optimally, if supported by learning planning with appropriate and systematic steps. Which means, the learning process can run optimally, if it is supported by learning plans which are appropriate and systematic steps. Of course, learning planning with the intended steps is related to strategies, models and approaches, and the use of learning resources. This is an absolute necessity in a learning activity process.

In essence, a learning planned by the teacher by using a variety of learning sources is certainly a learning strategy in which students are given the opportunity to construct their own knowledge through interaction with the various learning resources they obtained. According to Sitepu (2014), various source-based learning is a learning strategy that gives learners the opportunity to acquire and build their knowledge through interactions with various learning sources. In addition, it can also be considered a methodology because it allows learners to learn from their own efforts dealing with various sources of information so that they acquire skills in finding, sorting, selecting, and using information in the fields they are studying.

Learning resources that are used properly by teachers in learning greatly affect the response of students, related to activeness and achievement. Because learning resources are an indicator in determining the achievement of the learning objectives themselves, apart from indicators of teacher professionalism. If learning activities tend to use only certain learning resources (textbooks), the learning atmosphere becomes less effective and students will be more passive and bored. This kind of learning atmosphere still occurs in the world of education in this country. By prioritizing text books as the only source of learning. Learning situations like this should get the attention of teachers so that they can determine and vary learning by utilizing various learning resources.

According to Rahman Hamid (2014), learning history activities in the dominant class have used available textbooks according to the subject matter. Students and teachers use the book to learn the topic / material(Hamid Abd Rahman, 2014). In this model, students are accustomed to consuming "finished goods" or instantaneous knowledge products that have been formulated and 
interpreted by the author of the book. As a result, not infrequently students only accept historical knowledge and interpretation as it is, without a more critical effort to provide an interpretation of historical events. Therefore, based on the explanation above, it is appropriate for the teacher to choose and determine the right learning source, so that an effective and impressive learning atmosphere will be created.

\section{METHODS}

This research was conducted at SMA Negeri 5 Kota Ternate which is located at Jln. DufaDufa Village, North Ternate City District, Ternate City. This research uses qualitative methods with a descriptive approach. The data obtained in qualitative research with descriptive characteristics as stated by Moleong (2012: 11) states that the data collected is in the form of words, pictures, and not numbers. This is due to the application of qualitative methods(Moleong Lexy J, 2012). Moreover, everything that is gathered is likely to be the key to what has been researched. Thus, the research report will contain data citations to provide an overview of the presentation of the report. Such data may come from interview scripts, field notes, photos, videotapes, personal documents, notes or memos, and other official documents. The data obtained in this study, sourced from informants (resource persons) which include subject teachers, students and school principals. Meanwhile, to obtain data to support this research, data collection techniques are carried out through: observation, interviews, and documentation.

To find out the validity of the data, qualitative analysis with an inductive logic approach is carried out, in which the syllogism is built based on specific things or data in the field and leads to general conclusions. Thus, this approach uses the logic of thinking like a sitting pyramid, as shown below:

Facts / Data / Information

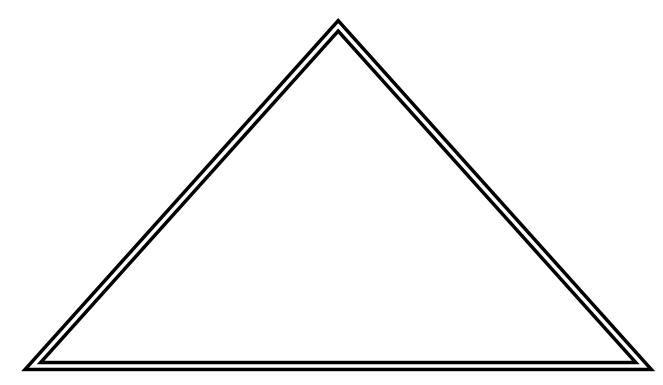

Conclusion Theory / Theory / Law

(Figure 1: Sitting Syllogism-Pyramid Data Analysis Model, in BurhanBungin). (Bungin Burhan H.M, 2014)

\section{RESULTS AND DISCUSSION}

Based on the research results obtained through observation, documentation and interviews with history teachers and students (students) illustrates the process of learning history by using a variety of learning resources. As stated in the Learning Program Plan (RPP), the learning resources used are in the form of materials, people, the environment, messages, tools and other equipment. The use of various learning resources in history learning at SMA Negeri 5 Ternate City is certainly a natural thing due to the adequate availability of various learning resources related to the environment. Where about -+250 meters from the SMA Negeri 5 Ternate City there is Fort Holandia (Toloko). The history teacher did not waste the existence of this fortress as a learning resource. This explanation was supported by the information given by the history subject teacher when the researcher conducted the interview. He explained that, in supporting history learning activities, it was not difficult for him to sort and choose learning sources. Because in our school, 
there are many sources of learning resources. Whether learning resources in the form of text books, people, and even the environment around the school also provides learning resources.

In addition, the use of learning resources in the form of tools is also carried out in history learning in its substance which aims to provide messages during the learning process. Of course the use of learning resources to make it easier for students to understand the material taught by the teacher in learning. The internet is a type of learning resource that is a tool. Supported by other equipment, for example, Laptop / computer, projector / focus and connected to the availability of internet networks at schools, it can help students understand the material presented by the teacher. The availability of school facilities and infrastructure can be strengthened by the explanation of the history teacher and school principal who said that every lesson the teachers always use are Laptops / notebooks and invoices that are scattered throughout the class / study room to help the learning process (interview results 6 March 2019).The use of various learning resources is very beneficial for teachers and students because the learning resources used can provide direct experience and make it easier for students to understand the material being studied.

According to interviews conducted with teachers of history subjects, it was suggested that the learning resources used were very supportive of the history learning process because learning resources are very beneficial, such as learning experiences, motivating students to be active, making it easier for students to understand the material, increasing imagination and increasing the concentration of students (interview results 8 March 2019).

On the other hand, according to the results of observations and interviews with informants, it is stated that, the learning resources that are material in SMA Negeri 5 Ternate City are: Modules, books and worksheets. When history lessons took place, text books were still an alternative source of learning. This is based on the explanation of the history subject teacher on Thursday, March 9, 2017, that the history learning process still often uses text books because they are in accordance with the lesson plans designed in accordance with the specified subject matter. In addition, the LKS used in history teaching is sometimes compiled by the history subject teacher because it is adjusted to the material being taught. While the use of the module as a learning resource by history teachers is used as a guide in providing learning materials.

In supporting history learning activities, of course, really needs or subject teachers. At SMA Negeri 5 Kota Ternate, there are 2 history teachers for four (4) classes. However, during the research, researchers only found 1 out of 2 history teachers, namely, Mr. Yakun, M.Pd, and he also helped researchers in finding data related to this research.

Learning is a process that is designed systematically by involving various components to achieve these learning objectives. One of the integrated components in learning is learning resources. As according to Far-Far (2020), learning is the spirit of the educational process in an educational institution. Factors that can affect the implementation of learning, namely, externally and internally include teaching staff (teachers), learning resources, methods, media and technology, learning conditions and systems.

Theoretically, many experts have defined the learning resources themselves. in general, the notion of learning resources contains a very broad meaning. According to the Association of Education and Communication Technology (AECT) in (Zainal Aqib, 2015), learning resources can be classified into 6 categories which areas follows: 1). Messages, namely information transmitted (forwarded) by other components in the form of ideas, facts, meanings and data. Included in the message group are all fields of study or courses that must be taught to students. 2). People (peoples), namely humans who act as storage, processing, presenter messages. 3). Materials, namely software that contains messages to be presented through the use of tools or by himself. 4). Devices, namely class devices used to convey messages stored in materials. 5). Techniques, namely procedures or references that are prepared using materials, equipment, people and the environment to convey messages. 6). Environment (setting), namely the surrounding situation in which the message is conveyed, the environment can be physical (school building, campus, library, laboratory, studio, auditorium, museum, park) or non-physical environment (learning atmosphere, etc.). 
Based on the various results of research conducted, the learning process using various sources has a profound impact on paradigm shifts in education. Reigeluth (1994) and Belt (1997) in (Sitepu B.P, 2014) provide examples of changes such as, the approach that was originally teacheroriented, shifted to students (student-oriented approach), from the assumption of learning space. Bordered by walls, floors and ceilings, expanding into a world without borders. From a strictly limited place and time to learn to learn freely. The evaluation system, which was originally based on mastering the subject matter, has changed to be based on mastery of ability. Learning resources that previously referred to textbooks, changed to refer to information and communication technology, as well as the environment around the school.

The process of learning change is oriented from the teacher as a source of knowledge shifts to students and the wider environment. The impact of learning like this is very significant for planning, implementing and evaluating learning. Overall, the learning process based on various sources refers more to the characteristics and interests of students. With learning planning carried out by the teacher about the objectives, methods, learning resources and evaluation. Then the teacher should consider the diversity of students' backgrounds. For example, the abilities of students, life background, intelligence and learning styles of each student. Considerations like this, are in line with what has been mandated in the curriculum which has set the standard of ability, basic ability or indicators of achievement of abilities that students want to achieve according to the lesson plan. It is important for a teacher to concretize these goals so that they have relevance to the lives of students today and in the future based on their respective environments.

Thus, in the use of learning resources more broadly and optimally, the teacher first understands earlier about the qualifications that refer to something that is used as a learning resource in learning. According to Rohani (2010) in general, before making a decision on learning resources, teachers need to consider the following aspects: a) (Rohani Ahmad, 2010). Economical or cost, is there a fee for the use of a learning resource (which requires costs. For example, overhead (OHP) and its transparency, video tape / TV and its cassettes, etc. b).Technician (personnel), namely either a teacher or another party who operates a particular tool that is used as a learning resource. There are special technicians / assistants or the teachers themselves, they are able to operate it. For example, how to operate slides, video tape / TV, laboratory, and so on. c). It is practical and simple, namely easy to reach, easy to implement, and not difficult / rare. d). flexible, that is, something that is used as a learning resource should not be rigid / patent, but it must be easy to develop, can be used to achieve learning objectives, not easily influenced by other factors. e). Relevant to learning objectives and other teaching components. f). Can help efficiently and then the achievement of learning goals. g). Has a positive value for the learning process / activity, especially students. h). In accordance with the interactions and learning strategies that have been designed/are being implemented.

History learning generally applied to education / school units looks dry, boring due to the chronicle approach by directing students / students to put more emphasis on memorization (FarFar, 2020b). According to Hamid that in history learning, teachers always prioritize appropriate approaches to answer the needs of students in following the learning process. This is important so that students do not seem bored, lazy, and not enthusiastic about participating in the history learning process as learning history emphasizes more on memorizing dates, years, places, figures. Learners are not constructed to describe a particular event in understanding the dynamics of change itself. So that learning history at school seems bored for students. This factor, of course, is very much due to not being supported by the right learning model and the support of relevant learning media. As explained above, it is certainly counterproductive to what Kochharin emphasized that history teachers have a very important role in the process of learning history. By developing forms of learning aids mechanically and developing education that focuses on student progress, history teachers are also required to be able to create an atmosphere in history learning that is more lively, as well as being able to attract students' attention in history learning. According to the Bank, Sylvester and Mays in (Far-Far, 2020a), "the implementation of history learning is highly expected to use historical sites in learning in schools". Students can be encouraged to find evidence of an event, so that it can be managed or to provide criticism / input on the source and interpret it, then 
the students arrange it into historical works / stories. In this position, educators / teachers are no longer a single source in providing information / knowledge in the classroom. Teacher plays a more role in many aspects, for example, as a guide for student activities.

In learning planning carried out by the teacher, with a learner-centered approach, it is of course very demanding that students always play an active role, both mentally and physically in learning. When knowing the abilities to be achieved in learning, the teacher guides students to find various information related to learning sources and learning styles of each student in order to be able to achieve the learning objectives that have been set. With the implementation of learning like this, the teacher plays a role in monitoring every activity carried out by students both individually and in groups. The goal, if there are students who have difficulty in learning, is for the teacher can guide and motivate students to improve the process and learning outcomes.

\section{CONCLUSIONS}

The use of learning resources in history learning has been done well. This is greatly supported by the various types of learning resources available at SMA Negeri 5 Ternate City. However, in the implementation of learning, the use of learning resources is still dominated by certain learning sources, for example, the type of learning resources for textbooks and the environment. Meanwhile, other types of learning resources have not been maximized properly by teachers to be used as learning resources. In addition, the learning planning carried out by the teacher, in relation to the use of learning resources, is still influenced by the tendency of the teacher without seeing and considering the desires or diversity of students.

As professional educators, teachers are always required to strengthen and increase competence and creativity because for a history teacher, to explain an event / incident that is too tens, hundreds or even thousands of years to students in today's life, of course, really requires ability and expertise so that history learning which is considered saturated and boring by students, is felt effective and impressive. Of course this hope can be achieved, if the teacher is able to design learning by utilizing a variety of learning resources according to the diversity of existing learning sources. On the other hand, students can be more active in utilizing various learning resources at school. If students can make good use of learning resources, they will not only gain knowledge about history, but they will also get new experiences in learning history.

The school principal, ideally makes regulations / policies in order to provide support for teachers to develop and improve learning resources. When the teacher is able to improve learning resources mechanically, it makes it easy for students to study and understand every material being lamed because in essence, school is a place for students to acquire knowledge. Thus, it is not an exaggeration if schools are always required to provide excellent service to students.

\section{REFFERENCES}

Baharuddin. H, \& W. E. N. (2015). Teori Belajar dan Pembelajaran. Ar-Ruz Media.

Bungin Burhan H.M. (2014). Penelitian Kualitatif. Prenada Media Group.

Far-Far, G. (2020a). Pemanfaatan Keraton Sultan Ternate Pada Pembelajaran Sejarah Lokal berbasis multicultural, Studi Kualitatif Deskriptif di SMA Negeri 5 Kota Ternate. Education and Human Development Journal, 5(2).

Far-Far, G. (2020b). Pengembangan Model Pembelajaran Sejarah Berbasis Situs Sejarah Lokal di SMA Negeri 5 Kota Ternate. Jurnal Pedagogika. Vol. 8 No. 1. Jurnal Pedagogika, 8(2).

Far-Far Gazali. (2020). Outstanding of learning Based on Using Historical Sites Colonial in Ternate City as a Source of Learning. International Journal of Education \& Curriculum Application, 3(2).

Hamid Abd Rahman. (2014). Pembelajaran Sejarah. Ombak. 
Hasan, Hamid, (1985). Pengajaran sejarah antara Harapan dan Kenyataan. Makalah Seminar Sejarah Nasional di Yogyakarta

Kochhar, SK, (2008). Pembelajaran Sejarah, Jakarta: Grasindo.

Moleong Lexy J. (2012). Metodologi Penelitian Kualitatif. PT Remaja Rosdakarya.

Musfiqon HM. (2012). Pengembangan Media dan Sumber Pembelajaran. Prestasi Pustakaraya.

Rohani Ahmad. (2010). Pengelolaan Pengajaran, Sebuah Pengantar Menuju Guru Profesional. Rineka Cipta.

Saefuddin H. Asis \& Berdiati Ika. (2016). Pembelajaran Efektif. PT Remaja Rosdakarya.

Sitepu B.P. (2014). Pengembangan Sumber Belajar. PT RajaGrafindo Persada.

Yana Wardhana. (2010). Teori Belajar dan Mengajar. PT Pribumi Mekar 